\section{Antarctic global warming?}

SIR - Doake and Vaughan ${ }^{1}$ report on the rapid disintegration of the Wordie Ice Shelf, Antarctica, using as evidence positions of the ice-shelf front in 1966 as mapped from aerial photography, and satellite images taken between 1974 and 1989. They attribute the disintegration of this floating mass of ice (from about $2,000 \mathrm{~km}^{2}$ in 1966 to about $700 \mathrm{~km}^{2}$ in 1989) to a warming trend in mean annual air temperature in Marguerite Bay, on the west side of the Antarctic Peninsula. Zwally ${ }^{2}$, in an accompanying News and Views article, relates this observation to the question of the future stability of the West Antarctic ice sheet.

On a smaller scale, but also relevant to the results of Doake and Vaughan, are changes in a glacial feature at Stonington Island $\left(68^{\circ} 11^{\prime} \mathrm{S}, 67^{\circ} \mathrm{W}\right)$, about 65 nautical miles north of the Wordie Ice Shelf $\left(69^{\circ} 15^{\prime} \mathrm{S}, 67^{\circ} 45^{\prime} \mathrm{W}\right)$. John Rymill, leader of the British Graham Land expedition (1934-37) established a camp on nearby Debenham islands, and was apparently the first to describe the snow ramp that connected Stonington Island to the mainland ${ }^{3}$. In 1939, the US Antarctic Service Expedition established East Base on the north end of Stonington Island, and also noted the "foot of a glacier which descended from the Antarctic Peninsula [that] tied Stonington Island to the mainland"4. FIDS (Falkland Islands Dependencies Survey) Base E was established in 1946, a year before the Ronne Antarctic Research expedition (1947-48) arrived at Stonington Island to reoccupy East Base. At this time, the snow ramp was still in place and connected the island to the mainland. Fraser ${ }^{5}$ noted the ramp in place in 1961-62, mapping its minimum width as $175 \mathrm{~m}$ and a gradient of near zero (sea level) to $30 \mathrm{~m}$ elevation in a horizontal distance of $100 \mathrm{~m}$. The ramp was thus a massive feature, essentially an extension of Northeast Glacier, and was used by these expeditions for access from the island to the mainland during sledging trips.

In February 1975, the US Antarctic Research Program's research vessel Hero entered Marguerite Bay and visited Stonington Island. The snow ramp was noted by Lipps ${ }^{6}$ as being in place at the time of his visit. On 28 February 1990, I was on the cruise ship Society Explorer, which sailed into Marguerite Bay and anchored near Stonington Island. I noticed that the snow ramp connecting Northeast Glacier on the mainland of the Antarctic Peninsula and Stonington Island was no longer there, but there was instead an open-water channel between Back Bay and the main part of Marguerite Bay. This channel was about
$50 \mathrm{~m}$ between the island and the vertical cliff face of Northeast Glacier, which was about $20 \mathrm{~m}$ high. When this snow ramp disintegrated and disappeared is unknown, although I made some attempts to establish the date as closely as possible.

C. Doake of the British Antarctic Survey provided a copy of a field diary from a British Antarctic Survey sledging team in July 1980, in which the ramp is described as having "a huge abyss separating ramp and glacier", and "many large crevasses and seracs ...." Jane G. Ferrigno of the US Geological Survey assisted me by locating six usable scenes of the 54 Landsat pictures of the Stonington Island area between 1973 and 1990. She examined the March 1986 and December 1978 images in photo format, and she states in a letter to me that these two "images seemed to show no disintegration of the ice although the latter image was partially obscured by cloud and shadow. The 1988 and 1989 images seemed to show a partial disintegration of the ice, but the microfiche was not adequate for accurate determination." I have since discovered no further conclusive evidence.

Northeast Glacier is but one small part of the ice margin of numerous glaciers on the Antarctic Peninsula but it, together with observations by Doake and Vaughan ${ }^{1}$ of the much larger Wordie Ice Shelf, can contribute to the effects of what might be a progressively warming period in this part of Antarctica, and subsequent retreat and disintegration of major ice shelves.

\section{Jameson Point Road,} JOHN SPLETTSTOESSER

Rockland, Maine 04841, USA

\footnotetext{
1. Doake, C. \& Vaughan, D. Nature 350, 328--330 (1991) 2. Zwally, H. Nature 350, 274 (1991).

3. Rymill, J. R. Geogr. J. 91, 424-438 (1938)

4. Bertrand, K. Am. Geogr. Soc. Spec. Pub. 39 (1971).

5. Fraser, A. G. British Antarctic Survey Sci. Rep. 52 (1965).

6. Lipps, J. US Antarctic J. 10, 211-219 (1976).
}

SIR - High mountain glaciers of the tropics are sensitive to climatic change. Mount Kenya's glaciers $\left(9^{\circ} 09^{\prime}\right.$ S, $37^{\circ} 19^{\prime}$ E) were largest in the late $1800 \mathrm{~s}$ and have since receded drastically. The maximum extents are preserved by glacial moraines, while later stages are documented by expeditions to the mountain; all glaciers were mapped by photogrammetry in 1963 and again in 1987 (refs 1,2). Earlier studies have indicated that the ice shrinkage during 1899-1963 was instigated by precipitation and temperature change, but essentially controlled by increased solar radiation absorption $^{1,3}$. The 1963 and 1987 mappings provided the basis for a quantitative evaluation of the climatic forcing of the observed ice changes over the past 25 years, particularly in the light of possible connections with the greenhouse effect.

In 1963-87 the total ice-covered area on Mount Kenya decreased by $40 \%$, or at a considerably faster rate than during 1899-1963. Moreover, in contrast to 1899-1963, during 1963-87 the rate at which mass was being removed from the ice surface, termed surface lowering or thickness change, was essentially independent of solar radiation. Thus, processes other than solar radiation must have been the controlling factors of the ice wastage. Of particular interest are the energy effects on the ice of changing atmospheric composition and humidity, and environmental warming. The allglacier mean ice thickness change from 1963 to 1987 amounted to $-14.5 \mathrm{~m}$, corresponding to $-50 \mathrm{~cm}$ liquid water equivalent per year. The energy required to dispose of this layer by melting is $5.4 \mathrm{Wm}^{-2}$.

Apart from energy considerations, decreased snowfall could also bring about a glacier shrinkage, but a precipitation decrease of the required large magnitude is not borne out by stations on the Kenya highlands. Similarly, enhanced solar radiation absorbtion resulting from changes in cloudiness, atmospheric turbidity, and glacier albedo related to increased dust deposition or less snowfall are all excluded, because these mechanisms would all lead to radiation-related differential thinning of the glaciers, which is not observed.

Therefore, the cause of the ice loss must be sought in changes in sensible and latent heat transfer and/or the net longwave radiation. We have examined the effect of small changes in environmental conditions on these energy forcings ${ }^{4}$, recognizing that the glaciers are in an elevation range of $4,600-5,000$ $\mathrm{m}(580 \mathrm{mb})$, near the annual-mean $0{ }^{\circ} \mathrm{C}$ isothermal surface, and that the temperature of the glacier surface cannot rise above $0{ }^{\circ} \mathrm{C}$. Particularly relevant to the latent heat forcing is the identification for the equatorial belt of a specific humidity increase of $0.6 \mathrm{~g} \mathrm{~kg}^{-1}$ in the layer $700-500 \mathrm{mb}$ over $1965-85$. This has been related to the global warming and greenhouse effect, and explained as a consequence of intensified sea-air interaction over the tropical oceans favoured by an increase in sea surface temperature ${ }^{5}$.

Based on a sensitivity analysis ${ }^{4}$, we find that the following combination of climatic forcings is the most plausible to 